\section{Sugars Unrelated to Brix Changes in Stored Citrus Fruits}

\section{Ed Echeverria ${ }^{1}$ and Mohamed Ismai1 ${ }^{2}$ \\ Citrus Research and Education Center, 700 Experiment Station Road, Lake Alfred, FL 33850}

Additional index words. 'Hamlin' oranges, 'Palestine' limes, 'Robinson' tangerines 'Marsh' grapefruit, postharvest

The Brix content of the fruit pulp of 'Hamlin' oranges (HO) [Citrus sinensis (L.) Osbeck], 'Robinson' tangerines (RT) [Citrus reticulate (Blanco)], and 'Palestine' sweet lime (PL) [Citrus limettiodes (Tan.)] continues to increase during postharvest storage (Echeverria and Ismail, 1987). Such an increase in Brix is not due to the loss of water and the consequential increase in solute concentration, since postharvest water loss in citrus is restricted to the peel (Purvis, 1983). Furthermore, the juice yield per fruit remained constant throughout storage, indicating that the observed changes in Brix are the result of physiological activity. Within the citrus industry, an increase in juice Brix denotes an increase in the content of monoand disaccharides and, consequently, a superior (sweeter) taste. But this may be a misconception, since the instruments used measure total amounts of soluble solids and not necessarily the simple sugars that impart sweetness to citrus juices. In this study, we examined the content of the three predominant sugars (major contributors to sweetness) in several citrus fruit cultivars during storage to determine the degree of sugar involvement in the postharvest changes in Brix.

Fruit (with the exception of PL) were purchased from a local packinghouse and delivered to the laboratory 1 day after harvest. PL were obtained from the Citrus Arboretum at the Division of Plant Industry (Florida Department of Agriculture), Winter Haven, Fla. Only fruit of uniform size and appearance were used. Fruit were washed, treated with $1000 \mathrm{ppm}$ of the fungicide thiabendazole, randomly sorted, and stored in boxes (paper bags for PL) at $\pm 15 \mathrm{C}$ and $95 \% \mathrm{RH}$. Each box contained $\approx 50$ grapefruit, 80 oranges, or 90 tangerines. Each bag contained 10 sweet limes. Storage times were 9 weeks for HO, 7 weeks for 'Marsh' grapefruit (MG) [Citrus paradisi (Macf.)], and 4 weeks for PL and RT. At sampling time, three individual boxes or bags (each box or bag constituted a replicate) were mechanically squeezed and the juice analyzed for Brix and sugars. Brix was

Received for publication 5 June 1989. Florida Agricultural Experiment Station Journal Series no. 8771. The cost of publishing this paper was defrayed in part by the payment of page charges. Under postal regulations, this paper therefore must be hereby marked advertisement solely to indicate this fact.

'Assistant Professor, IFAS, Univ. of Florida.

${ }^{2}$ Research Scientist 111, Florida Dept. of Citrus. the averages of triplicate samples. determined using an American Optical table top digital refractometer. Hydrometric Brix measurements did not differ significantly (data not shown). The method of Nelson (1944) was used for estimating reducing sugars, For sucrose determination, samples were incubated for $2 \mathrm{hr}$ with and without invertase before glucose analysis. Glucose was analyzed by the glucose oxidase method (Kilburn and Taylor, 1969). Fructose was calculated as the difference between reducing sugars and glucose.

Brix content increased significantly in $\mathrm{HO}$, $\mathrm{RT}$, and PL but remained unchanged in MG (Table 1). Brix rose from 8.1 to 9.5 in $\mathrm{HO}$, from 10.9 to 12.1 in RT, from 7.6 to 8.2 in PL, and from 10.2 to 10.5 in MG during the respective storage periods. Concurrently, total sugars increased substantially in $\mathrm{HO}$ and RT but declined in PL and MG (Table 1).

Theoretical values for the Brix and sugar data are presented in Table 1. These calculated values are those expected if the changes in Brix were due only to parallel variations in sugars. In $\mathrm{HO}$, for example, an increase of 1.4 Brix would signify an increment of $14 \mathrm{mg}$ solids $/ \mathrm{ml}$. Since sucrose corresponds to $46 \%$ of the total sugars at storage time (Table 2), then a $6.4 \mathrm{mg} \cdot \mathrm{ml}^{-1}$ increase in sucrose is expected if the same ratio is to be maintained. Specific other changes are given in Table 1. The measured increase in sucrose was $13 \mathrm{mg} \cdot \mathrm{ml}^{-1}$, with glucose and fructose increasing $0.8 \mathrm{mg} \cdot \mathrm{ml}^{-1}$ combined. The dou- bling above the expected levels of sucrose compensates for the minimal change measured for the two hexoses. In general, the increase in sugar concentration (due mainly to sucrose) accounted for the measured rise in Brix for HO. In RT, however, the changes in sugars did not account for the increase in Brix. The increase in total sugars was $\approx 65 \%$ of the calculated values in RT, whereas in PL a decline in total sugars was observed, although Brix increased significantly (Table 1). Similarly, in MG, Brix remained unchanged, but total sugars also declined significantly.

Additional sugars that may contribute to the increases in Brix content of stored citrus fruit (or to discrepancies between Brix and sugar changes) could arise from the conversion of organic acids to sugars through gluconeogenesis (Echeverria and Valich, 1989). Also, solubilization of cell wall constituents by galactosidases and glucosidases may be involved (J. Burns, 1990).

We conclude that the increase in Brix observed in some citrus fruit cultivars during storage is not necessarily directly related to corresponding changes in the fruit's simple sugar content.

\section{Literature Cited}

Burns, J.R. 1990. Galactosidase activities in juice vesicles of stored Valencia oranges. Phytochemistry. (In press.)

Echeverria, E. and M. Ismail. 1987. Changes in sugars and acids of citrus fruits during storage. Proc. Fla. State Hort. Soc. 100:50-52.

Echeverria, E. and J. Valich. 1989. Enzymes of sugar and acid metabolism in stored Valencia oranges. J. Amer. Soc. Hort. Sci. 114:445-449.

Kilburn, D.M. and P.M. Taylor. 1969. Effect of sulfhydryl reagents on glucose determination by the glucose oxidase method. Anal. Biochem. 27:555-558.

Nelson, N. 1944. A photometric adaptation of the Somogy method for determination of glucose. J. Biol. Chem. 153:375-380.

Purvis, A. 1983. Moisture loss and juice quality from waxed and individually sealed-packaged citrus fruits. Proc. Fla. State Hort. Soc. 96:327329.

Table 1. Values for observed $(\mathrm{O})$ changes in Brix and sugars during storage, and the theoretical values (T) of sugars for the observed increases in Brix.

\begin{tabular}{|c|c|c|c|c|c|c|c|c|c|}
\hline \multirow[b]{2}{*}{ Fruit } & \multirow{2}{*}{$\begin{array}{c}\text { Brix } \\
\text { change }\end{array}$} & \multicolumn{2}{|c|}{ Sucrose } & \multicolumn{2}{|c|}{ Glucose } & \multicolumn{2}{|c|}{ Fructose } & \multicolumn{2}{|c|}{ Total sugar } \\
\hline & & $T$ & $\mathrm{O}$ & $\mathrm{T}$ & 0 & $\mathrm{~T}$ & 0 & $\mathrm{~T}$ & 0 \\
\hline & & \multicolumn{8}{|c|}{$\left(m g \cdot m l^{-1}\right)$} \\
\hline Hamlin orange & +1.40 & 6.4 & 13.0 & 2.7 & 0.1 & 4.8 & 0.7 & 13.9 & $13.8^{y}$ \\
\hline Robinson tangerine & +1.20 & 6.4 & 4.4 & 3.1 & 2.0 & 2.5 & 1.1 & 12.0 & 7.5 \\
\hline Palestine lime & +0.60 & 0.4 & -2.3 & 3.2 & 2.5 & 2.4 & -1.1 & 6.0 & -0.9 \\
\hline Marsh grapefruit & $+0.13^{z}$ & 0.6 & -1.6 & 0.3 & $0.4^{y}$ & 0.4 & -5.1 & 1.3 & -6.3 \\
\hline
\end{tabular}

${ }^{7}$ Not significantly different from initial value at the $5 \%$ level by $t$ test (Brix changes) $(\mathrm{P} \leq 0.05)$.

'Not significantly different from initial value at the $5 \%$ level by $x^{2}$ test $(P \leq 0.05)$.

Table 2. Sugar content of several citrus cultivars at harvest time (1) and after storage (F). Values are

\begin{tabular}{|c|c|c|c|c|c|c|c|c|}
\hline \multirow[b]{2}{*}{ Sugar } & \multicolumn{2}{|c|}{$\begin{array}{c}\text { Hamlin } \\
\text { orange }\end{array}$} & \multicolumn{2}{|c|}{$\begin{array}{l}\text { Robinson } \\
\text { tangerine }\end{array}$} & \multicolumn{2}{|c|}{$\begin{array}{c}\text { Palestine } \\
\text { lime }\end{array}$} & \multicolumn{2}{|c|}{$\begin{array}{c}\text { Marsh } \\
\text { grapefruit }\end{array}$} \\
\hline & I & $\mathrm{F}$ & I & $F$ & I & $F$ & I & $\mathrm{F}$ \\
\hline & \multicolumn{8}{|c|}{$\left(m g \cdot m l^{-1}\right)$} \\
\hline Sucrose & 35.2 & 48.2 & 39.8 & 44.2 & 3.8 & 1.5 & 42.6 & 41.0 \\
\hline Fructose & 26.3 & 27.0 & 14.5 & 15.6 & 22.6 & 21.5 & 22.3 & 17.2 \\
\hline Glucose & 15.0 & 15.1 & 17.4 & 19.4 & 30.0 & 32.5 & 22.5 & 22.9 \\
\hline Total & 76.5 & 90.3 & 71.7 & 79.2 & 56.4 & 55.5 & 87.4 & 81.1 \\
\hline
\end{tabular}

